\title{
The Outcome of Colorectal Surgery in Cirrhotic Patients: A Case Match Report
}

\author{
Monica Lacatus ${ }^{1,2}$, Laura Costin ${ }^{1}$, Virgil Bodean', Mircea Manuc ${ }^{2,3}$, Cătălin Vasilescu ${ }^{1,2}$ \\ 'Department of General Surgery and Liver Transplatation, Fundeni Clinical Institute, Bucharest, Romania \\ 2"Carol Davila" University of Medicine and Pharmacy, Bucharest, Romania \\ ${ }^{3}$ Department of Gastroenterology and Hepatology, Fundeni Clinical Institute, Bucharest, Romania
}

Corresponding author:

Professor Catalin Vasilescu

Fundeni Clinical Institute

258 Fundeni Street

Bucharest, Romania

E-mail: catvasilescu@gmail.com

\section{Rezumat}

\section{Chirurgia colorectală la pacientul cirotic}

Introducere: Chirurgia colorectală la pacientul cirotic a reprezentat dintotdeauna un subiect controversat, având indicații limitate. Însă, aşa cum şi studiul îşi propune să demonstreze, evaluarea atentă a factorilor de risc poate să extindă aceste indicații.

Pacienți şi metodă: În perioada ianuarie 2011- ianuarie 2016, în Clinica de Chirurgie Generală şi Transplant Hepatic din cadrul Institutului Clinic Fundeni, au fost operați 68 de pacienți cu cancer colorectal şi ciroza hepatică. Lotul a fost comparat cu 136 de pacienți cu neoplasm de colon sau rect, însă fără suferință hepatică. În acest sens au fost evaluați factorii de risc, morbiditatea şi mortalitatea.

Rezultate: Factori de risc specifici precum stadiul afectiunii hepatice (scorul Child, MELD), etiologia bolii, gradul de hipoalbuminemie şi prezența ascitei, precum şi vârsta pacienților influențează evoluția postoperatorie. Rata de reintervenție a fost mai mare în grupul cirotic fiind influențată de tipul operatiei, metoda de abord şi nivelul de urgență (10.2\% vs. 5.1\%). Morbiditatea înregistrată în grupul pacienților cirotici a fost mai mare față de lotul martor $47.1 \%$ vs. $27.9 \%$ ( $=0.035)$; aceeaşi tentință a fost observată şi în cazul mortalității $5.9 \%$ vs. $2.2 \%$. $(\mathrm{p}=0.2)$. Pacienții din grupul Child $\mathrm{C}$ au înregistrat procente mari de morbiditate şi mortalitate, $75 \%$ respectiv $50 \%$.

Concluzie: Pacienții cu ciroză Child A pot fi tratați chirurgical, fără riscuri adiționale față de populația generală. Grupul Child B necesită evaluare preoperatorie atentă, iar cei din Child $\mathrm{C}$ vor fi abordați mai degrabă conservator. 
Cuvinte cheie: ciroza hepatica; chirurgie colorectala; morbiditate; mortalitate

\begin{abstract}
Background: Colorectal surgery in cirrhotic patients has had limited indications, but as the study aims to show, careful evaluation of risk factors can extend boundaries.

Methods: From January 2011 to January 2016, using a case match cohort, 68 patients with colorectal malignancy and cirrhosis were compared against 136 persons with no liver disease. Significant risk criteria, morbidity and mortality were evaluated.

Results: When analyzing specific risk factors - age, etiology and severity of liver disease (MELD, Child-Pugh score, ascites and hypoalbuminemia) were found to be significant to surgical outcome. Approach and type of intervention as well as emergency status reflected upon reintervention rates with $10.2 \%$ in the cirrhotic population vs $5.1 \%$ in the non-cirrhotic one $(\mathrm{p}=0.3)$. Postoperative morbidity was higher in the chronic liver disease patients - $47.1 \%$ vs $27.9 \%$ in the case-match group $(\mathrm{p}=0.035)$. Mortality rate in the cirrhotic population was $5.9 \%$ while in the non-cirrhotic one was $2.2 \%(\mathrm{p}=0.2)$. Child $\mathrm{C}$ patients had a morbidity and a mortality rate of $75 \%$ and $50 \%$ respectively. Conclusion: Child A patients can be treated no different than the general population; Child B group needs proper assessment and care while in Child C population surgery should at all costs be avoided.
\end{abstract}

Key words: liver cirrhosis, colorectal surgery, morbidity, mortality

\section{Introduction}

Patients with liver cirrhosis are considered to be a particular group of surgical candidates because of their high morbidity and mortality rates. Digestive surgery in this population has long been limited to the treatment of disorders related to the liver disease. Nevertheless these patients may require non-hepatic surgical procedures, including emergency ones. Over the past decades, advances in medical care have improved outcomes in this particular group; therefore more cirrhotic individuals are proposed for surgery. Although postoperative outcomes are poorer than in the general population, few studies have examined specific risks of colorectal surgery in patients with chronic liver disease.

The aim of this report is to evaluate morbidity, mortality and significant risk criteria of colorectal surgery in patients with liver cirrhosis in order to help set proper indications for the surgical act in these fragile candidates.

\section{Patients and Method}

From January 2011 to January 2016, 68 cirrhotic patients with malignancies of either colon or rectum underwent surgery in our institution. A case-match cohort of 136 patients with colorectal malignancy but no liver disease was randomly selected for comparison.

This was a retrospective, case-control, single-center study aimed to evaluate morbidity, mortality and significant risk criteria of colorectal surgery in patients with liver cirrhosis, compared with the general population of colorectal cancer patients.

Patients were selected regardless of their age and gender. The cirrhotic cohort was matched according to the tumor site with the non-cirrhotic population in a ratio of $1: 2$. Cardiovascular pathology, chronic obstructive pulmonary disease, diabetes mellitus, obesity and anemia were the most frequent comorbidities found in both groups.

All cirrhotic patients included had either a prior diagnosis of cirrhosis or were diagnosed 
per-operatively by the means of a liver biopsy. Consequently they were classified according to their etiology. The CTP stage of the liver disease played a key role in analyzing the outcome of the surgical act as well as hypoalbuminemia and ascites.

Performed surgical procedures included both resection of the tumor with an astomosis as well as resection with a terminal stoma.

The surgical approach (open vsminimally invasive - laparoscopic or robotic) and the emergency status of the intervention were considered when assessing the postoperative outcome, judging in terms of surgical complications, re-interventions and status on discharge.

In order to classify post-operative complications the Clavien-Dindo (CD) score was used. Patients with score 1 had minor complications. Both groups developed wound infections whereas the cirrhotic population also developed mild ascites. Score 2 was assigned to patients with peri-anastomotic abscesses that were treated in a conservative fashion and ascites that needed medication to be controlled. All other post-operative complications, such as cardiovascular and pulmonary were also scored 2. Finally, a score 3 was given to patients with re-interventions for either hemorrhagic, obstructive, abdominal wall or septic complications (anastomotic leakage).

Statistical analysis was performed using SPSS. All continuous variables were represented using the median (with a range) and all other results were reported in percentages. Analysis was made using $\chi^{2}$ test, Fisher's exact test or Mann-Whitney test.

\section{Results}

Fundeni Clinical Institute records were searched and a database of 68 patients to be included in the study was rendered. These patients were compared against 136 non- $^{-}$ cirrhotic patients, with colorectal malignant tumors but without cirrhosis.

The median age was 65 (44-86) years old in the cirrhotic patients group and $66(41-88)$ in the case-match group. Sex ratio was $\mathrm{M}: \mathrm{F}-3: 1$ in the cirrhotic group and 1.77:1 in the casematch group (Table 1).

According to the tumor site cirrhotic patients and controls were matched in a ratio of 1:2 as follows- 18:36 right colon cancer, 26: 52 left colon neoplasms, 21:42 rectal cancer and 3:6 synchronous neoplasms.

Regarding liver disease etiology classification, $50 \%$ had viral hepatitis, $36.8 \%$ were recorded as alcohol-related cirrhosis while $13.2 \%$ had cryptogenic cirrhosis.

Considering the severity of the liver disease, 49.2\% (34 patients) had a CTP A score. Child B group accounted for 44.9\% (31 patients) and $5.9 \%$ were CTP C. MELD score was also calculated- with a median of 9 (Table 2).

An anastomosis was carried out in $44.1 \%$ of the cases in the cirrhotic population group in

Table 1. Collected data- Demographic, surgical technique and approach information

\begin{tabular}{lccc}
\hline & $\begin{array}{c}\text { Cirrhosis } \\
(\mathbf{N}=\mathbf{6 8})\end{array}$ & $\begin{array}{c}\text { Match - case } \\
(\mathbf{N}=\mathbf{1 3 6})\end{array}$ \\
\hline Mean age & $65.57+/-8,764$ & $65.22+/-8.654$ & $\mathrm{P}=0.1$ \\
\hline Males & $75 \%$ & $64 \%$ & \\
\hline Site & & & 36 \\
$\quad$ - Right colon & 18 & 52 & \\
- Left colon & 26 & 42 & \\
- Rectum & 21 & 6 & $\mathrm{P}=0.001$ \\
- Synchronous & 3 & $27.9 \%(\mathrm{~N}=38)$ & $\mathrm{P}=0.015$ \\
\hline Colostomy & $55.9 \%(\mathrm{~N}=38)$ & $18.4 \%(\mathrm{~N}=25)$ & $\mathrm{P}=0.8$ \\
\hline Minimal invasive surgery & $5.4 \%(\mathrm{~N}=4)$ & $22.1 \%(\mathrm{~N}=30)$ & \\
\hline Emergency surgery & $20.5 \%(\mathrm{~N}=14)$ &
\end{tabular}


Table 2. Etiology and MELD of the cirrhotic population according to the Child-Pugh score

\begin{tabular}{lcccc}
\hline & $\begin{array}{c}\text { Child } \mathbf{A} \\
(\mathrm{N}=\mathbf{3 4})\end{array}$ & $\begin{array}{c}\text { Child B } \\
(\mathrm{N}=\mathbf{3 0})\end{array}$ & $\begin{array}{c}\text { Child C } \\
(\mathbf{N}=\mathbf{4})\end{array}$ & \\
\hline Males & $82.4 \%(\mathrm{~N}=28)$ & $66.7 \%(\mathrm{~N}=20)$ & $75 \%(\mathrm{~N}=3)$ & $\mathrm{P}=0.27$ \\
\hline Etiology & & & & $\mathrm{P}=0.3$ \\
- Unknown & $17.3 \%(\mathrm{~N}=6)$ & $6.7 \%(\mathrm{~N}=2)$ & $25 \%(\mathrm{~N}=1)$ & \\
- Toxic & $38.2 \%(\mathrm{~N}=13)$ & $40 \%(\mathrm{~N}=12)$ & $0 \%$ & \\
- Viral & $44.1 \%(\mathrm{~N}=15)$ & $53.3 \%(\mathrm{~N}=16)$ & $75 \%(\mathrm{~N}=3)$ \\
\hline Mean MELD score & $8.26 \pm 1.420$ & $9.36 \pm 2.141$ & $12.5 \pm 1.732$ & \\
\hline
\end{tabular}

comparison to the case-match cohort where $84.5 \%$ were treated in this fashion.

The approach was minimally invasive in $8.8 \%$ (3 robotic and 1 laparoscopic) of the cirrhotic population - with a conversion rate of $33.3 \%$. On the other hand $22.8 \%$ (8 robotic and 17 laparoscopic) of the case match group were treated in this fashion with a conversion rate of $16.6 \%$. $(p=0.015)$.

Emergency surgery was performed in $20.5 \%$ (14 patients) of the cirrhotic cohort and 22.1\% (30 patients) of the non-cirrhotic one, due to either hemorrhagic or obstructive type of the tumors. Reintervention was needed in $14.2 \%$ of the cirrhotic population with $16.6 \%$ deaths, compared to only $9.6 \%$ reinterventions in the case match and a mortality rate of $3.22 \%$.

Postoperative morbidity was significantly higher in the cirrhotic group, namely $47.1 \%$ versus $27.9 \%(p=0.035)$. Multiple risk factors were assessed.

When analyzing specific risk factors, age over 70, hypoalbuminemia and ascites were identified to influence the postoperative outcome in the cirrhotic population. Patients 70 years old and over had a higher rate of complications, as $56 \%$ of them developed a post-operative issue, in comparison to the ones under 70 that only registered a $36.6 \%(\mathrm{p}=0.3)$. A cut-off for albumin levels was set at $3 \mathrm{mg} / \mathrm{dl}$. Results showed that $65 \%$ of patients with a lower value versus $41 \%$ with higher albumin levels had a complicated outcome $(\mathrm{p}=0.08)$. In addition, all cirrhotic patients that presented with ascites required treatment postoperatively in order to control it. A percentage of $6.2 \%$ of them deceased.

One comorbid condition was noticed to have a detrimental effect on the evolution. All three patients with chronic obstructive pulmonary disease developed post-operative complications and one of them died.

Etiology played an important role as $62.5 \%$ of the patients with septic complications had nutritional cirrhosis.

In the cirrhotic cohort,only 1 patient (2.6\%) with a terminal stoma developed a complication related to it (a colostomy necrosis) vs $13.3 \%$ of the patients that had an anastomosis performed. In the case-match cohort, 10.5\% stoma related issues were noted vs $8.1 \%$ septic complications in the anastomosis group.

In the chronic liver disease group all patients approached minimally invasived had an uneventful postoperative course.

MELD score was also used as a predictor for poor outcome. Patients with a score of 0-11 had a mortality rate of $3.3 \%$, while scores greater than 12 rendered a mortality rate of $28 \%(\mathrm{p}=0.05)$ (Table 3).

Regarding postoperative morbidity, CTP A patients showed no statistical difference to the non-cirrhotic ones: $35.3 \%$ vs. $27.2 \%$. By contrast, a significant difference was observed $(\mathrm{p}=0.002)$ when comparing the CTP B cirrhosis population, which registered $56.6 \%$ of patients with complications.

Three patients had reinterventions in CTP A cohort (8.8\%), with no statistical significant difference to the case match $(\mathrm{p}=0.6)$. On the other hand in the CTP B category $10 \%$ of the patients had a second surgery performed $(\mathrm{p}=0.38)$ (Table 4).

For patients with Clavien Dindo score 1 $13.2 \%$ of the non-cirrhotic group vs $8.8 \%$ of the cirrhotic population had complications such as 
Table 3. Morbidity and mortality of the cirrhotic population according to the Child-Pugh score compared to the match-case population

\begin{tabular}{|c|c|c|c|c|c|c|}
\hline \multirow[b]{2}{*}{ Complications } & \multicolumn{3}{|c|}{$\begin{array}{l}\text { Child A } \\
(\mathrm{N}=34)\end{array}$} & \multirow{2}{*}{$\begin{array}{l}\begin{array}{l}\text { Match case } \\
(\mathrm{N}=136)\end{array} \\
27.2 \%(\mathrm{~N}=38)\end{array}$} & \multicolumn{2}{|c|}{$\begin{array}{l}\text { Child B } \\
(\mathrm{N}=30)\end{array}$} \\
\hline & $35.3 \%$ & $(\mathrm{~N}=12)$ & $P=0.4$ & & $56.7 \%(\mathrm{~N}=17)$ & $P=0.02$ \\
\hline Reintervention & $8.8 \%$ & $(\mathrm{~N}=3)$ & $P=0.6$ & $5.1 \% \quad(N=7)$ & $10 \% \quad(N=3)$ & $P=0.38$ \\
\hline Hospital stay days & 8 days & & $P=0.3$ & 7 days & 9 days & $P=0.046$ \\
\hline Mortality & $2.9 \%$ & $(\mathrm{~N}=1)$ & $P=1$ & $2.2 \% \quad(N=3)$ & $3.3 \% \quad(N=1)$ & $\mathrm{P}=0.5$ \\
\hline
\end{tabular}

Table 4. Post-operative outcomes and mortality rates according to specific risk factors

\begin{tabular}{lcccc}
\hline & Complications & \multicolumn{3}{c}{ Mortality } \\
\hline Age $>70$ & $56 \%$ & $\mathrm{P}=0.3$ & $8 \%$ & $\mathrm{P}=0.6$ \\
\hline Hypoalbuminemia $(<3 \mathrm{mg} / \mathrm{dl})$ & $65 \%$ & $\mathrm{P}=0.8$ & $15 \%$ & $\mathrm{P}=0.07$ \\
\hline Colostomy & $50 \%$ & $\mathrm{P}=0.5$ & $5.3 \%$ & $\mathrm{P}=1$ \\
\hline Minimal invasive surgery & $50 \%$ & $\mathrm{P}=1$ & $0 \%$ & $\mathrm{P}=1$ \\
\hline Meld score $>12$ & $71.4 \%$ & $\mathrm{P}=0.25$ & $28.6 \%$ & $\mathrm{P}=0.05$ \\
\hline Meld Score $<12$ & $45.9 \%$ & $\mathrm{P}=0.25$ & $3.3 \%$ & $\mathrm{P}=0.05$ \\
\hline
\end{tabular}

wound infections and ascites respectively.

CD score 2 patients had a total of $10.2 \%$ post-operative issues in the case match as opposed to $29.4 \%$ in the cirrhosis group. In this latter group a percentage of $4.4 \%$ developed a peri-anastomotic abscess, another $18.5 \%$ ascites that required treatment, $4.4 \%$ had pulmonary septic complication and 2.1\%a cardiovascular event. In the matched cohort $6.6 \%$ had an anastomotic abscess.

Seven cirrhotic patients developed complications that needed a second surgery to be performed; 3 were for a hemorrhagic complication, 2 for obstructed bowels, 1 for anastomotic leakage and 1 for a colostomy necrosis. Therefore $10.2 \%$ of the cirrhotic population needed a reintervention. In the case-match cohort a percentage of only $5.1 \%$ was recorded. $(p=0.3)$. Four patients had a second surgery for fistulas, 2 patients for obstructed bowels and 1 had a parietal complication - an evisceration.

Two chronic liver disease patients developed encephalopathy as a result of the hepatic dysfunction and both of them were deceased.

The overall median hospital stay was 9 days for the cirrhotic population and 7 for the case-match $(p=0.022)$. The calculated hospital stay for Child B patients (9 days) was higher than the one for non-cirrhotic patients $(\mathrm{p}=0.04)$, while between Child A patients ( 8 days) and the case-match group no relevant difference was observed $(\mathrm{p}=0.3)$.

The mortality rate in the cirrhotic population was $5.9 \%$ while in the non-cirrhotic group was $2.2 \%(p=0.2)$. A $2.9 \%$ mortality rate was registered in the Child A group in comparison to CTP B -3.3\% and CTP C- 50\%. In the chronic liver disease group, $75 \%$ of deaths were related to septic complications.

Child $\mathrm{C}$ patients fall into a different category when it comes to complications and mortality. Only 4 patients with Child C cirrhosis were operated. Etiology was viral in three cases and 1 cryptogenic. Only one end-to-end anastomosis was performed and no intervention was minimally invasive. Two patients were operated as an emergency -1 hemorrhagic and 1 bowel obstructive tumor. The mean number of hospital stay was 16 days. Two deaths were recorded.

\section{Discussions}

Colorectal cancer in patients with liver cirrhosis has some particular features. A study using the Nationwide Inpatient Sample database of patients undergoing colorectal surgery between 
2006 and 2008 identified chronic liver disease as the most significant risk factor associated with mortality (1)

In order to better emphasize this fact, our study compared two sets of patients, one cirrhotic one non-cirrhotic and analyzed the differences.

A higher rate of male patients was observed in the chronic liver disease group, possibly due to the fact that only $11.8 \%$ women had alcohol related cirrhosis. Men typically drink more than women, and the proportion of heavy drinkers and alcoholics is much higher amongst them, this being reflected in the fact that mortality rates are about two times higher in men than in women in this type of patients (2). Therefore male patients seem to be at higher risk of developing liver associated dysfunctions that can complicate the postsurgical evolution.

Other important predictors were found to be age over 65, ascites and hypoalbuminemia. This is also the case in our study, where all these three factors were considered responsible for the poor outcomes (1, 3-6).

Ziseret al. identified diagnosis of cryptogenic cirrhosis and chronic obstructive pulmonary disease as additional parameters that can influence the post-surgery development of the cirrhotic patients (7).

Our study revealed that while chronic obstructive pulmonary disease was directly linked to septic complications and a higher rate of morbidity, the cryptogenic cirrhosis had no relevant impact on the post-operative course. On the contrary, alcohol related cirrhosis increased the risk to develop septic complications.

Rice et al. identified several parameters associated with 30-days mortality: encephalopathy, emergent surgery, infection, hypoalbuminemia. Encephalopathy independently predicted mortality $(3,4,8)$. Our study relates to these findings as encephalopathy has a mortality rate of $100 \%$. Emergency surgery carries itself a greater risk for re-intervention and death as shown in our statistics also, therefore morbidity and mortality are increased proportionally with this element.
In respect with the type of surgery, more invasive operative procedures involving the digestive tract have a worse postoperative outcome $(5,9)$. According to an article by Adani GL laparoscopic assisted colorectal surgery can be performed with an acceptable morbidity and probably with a lower mortality, but careful selection is crucial $(10,11)$. Even though laparoscopy scored a lower percentage in the cirrhotic population in our study, no post-operative complications were registered, suggesting minimal invasive approach is feasible and more patients should be proposed for this type of surgery.

There is a consensus that CTP and MELD scores provide a reasonably precise estimation of perioperative mortality. Mortality rates according to the CTP class A, B and C were $6 \%, 13 \%$ and $28 \%(12,13)$. Lower rates were found in our study CTP A and B patients $(2.9 \%$ and $3.3 \%$ ), with an impressive $50 \%$ mortality rate for Child $\mathrm{C}$ population. They concluded that CTP classification predicts the risk of postoperative death, which was also the case in our cirrhotic cohort.

The MELD score has been validated as an independent prediction tool to calculate postoperative mortality. A retrospective analysis by Northup et al found that the MELD score was the only statistically significant predictor of 30day mortality. It was estimated that scores of 0 - 11 correlate with $5 \%-10 \%$ mortality rates, 12 25 with $25 \%-54 \%$ mortality rates, and scores greater than 26 with a $90 \%$ postoperative mortality rate.Our cut-off at 11 with similar mortality rates confirms that MELD score can be an indicator for fatal events (14-17).

Postoperative complications include ascites, infection, bleeding and anastomotic fistulas (4, $18,19)$. Both populations in our study were analyzed and significantly higher percentages of such issues were recorded in the chronic liver disease cohort. Moreover, it appears that performing stomas in cirrhotic patients carries itself specific complications such as peri-stomal infection, leakage or evisceration (20). Therefore, the investigators concluded that patients with chronic liver disease should have an anastomosis rather than a terminal stoma. A much lower rate 
of complications was noticed in our patients that had a colostomy performed as opposed to those with an anastomosis, so according to our experience performing a stoma is safer.

The study of Meunier found a postoperative morbidity of $77 \%$ with a mortality of $26 \%$ (4). Among the patients who died 54\% were emergency operations, usually for peritonitis. The most important predictors for mortality were: presence of peritonitis, postoperative complications, in particular infections. Although ascites was not a risk factor, they stated that it could transform an anastomotic leakage into peritonitis $(4,18)$. An important percentage of our cirrhotic study group developed infection issues- para-anastomotic abscesses, fistulas and pulmonary afflictions. Three out of four deaths recorded were subsequent to septic complications.

The present study aims to raise awareness upon the risks of colorectal surgery in cirrhotic patients, showing that operating on these patients might not always be such a stumbling rock (21). Particularly, Child A patients can generally be considered to be no different that the non-cirrhotic population (22). Even though statistically this could not be confirmed, this is only due to the fact that in terms of post-operative complications Child A patients besides wound infections, which is a general complication, develop ascites additionally in a small percentage. But since no treatment was required and the hospitalization stay was not greatly influenced, there was virtually no difference between these two categories.

On the other hand, Child B patients showed statistically significant higher rates of complications, re-interventions and hospitalization stay. Therefore, these patients need proper assessment, management of hepatic function and other comorbid conditions prior to surgery. Preoperative portal decompression may be useful. Evaluating clinical and paraclinical information remains the key to a correct decision. Correction of risk factors such as hypoalbuminemia and ascites, as well as careful treatment and supervision of other comorbid conditions can definitely improve outcomes and extend indications for surgical treatment. Last but not least, team-work with the IC unit can render hope for this type of fragile patients (23).

In Child-Pugh $\mathrm{C}$ patients, who have limited life expectancy, surgery should be avoided if possible and non-surgical options should be used.

Mortality in colorectal surgery was generally reported between $1 \%$ and $6 \%$ (24) but associated liver cirrhosis represents a major risk factor that increases in-hospital morbidity and mortality up to $77 \%$ and $26 \%$ respectively. A retrospective analysis performed by Gervaz $\mathrm{P}$ et al. at the Mayo Clinic on 72 patients with colorectal cancer and cirrhosis found an overall postoperative mortality and morbidity rate of $13 \%$ and $54 \%$ (13).

The study is limited mainly because of the fact that the cirrhotic cohort numbers few patients and all statistical data referring to it becomes difficult to interpret.

\section{Conclusions}

Identifying preexisting problems that could be optimally and appropriately managed before surgery may reduce the risks and decrease mortality. Careful preoperative preparation and monitoring to detect complications early in the postoperative course are essential to improve outcomes. Management needs to be individualized and should include optimization of hepatic function and other comorbidities in a multidisciplinary team.

Child A patients benefit from surgical treatment to the same extent as the general population does. Extensive attention should be paid towards Child B cirrhotic population that needs proper assessment prior, during and post intervention. In Child $\mathrm{C}$ patients surgery should at all costs be avoided.

\section{Authors' Contributions}

Monica Lacatus and Laura Costin share first authorship. Monica Lacatus and Laura Costin data interpretation, drafting the manuscript and critical revision. Virgil Bodean - data analysis. Mircea Manuc - critical revision. Catalin Vasilescu - conception and design 
of the paper. Reviewing the article before submission not only for spelling and grammar but also for its intellectual content; final approval.

\section{Conflict of Interest}

All authors declare no conflict of interest.

\section{References}

1. Masoomi H, Kang CY, Chen A, Mills S, Dolich MO, Carmichael JC, et al. Predictive factors of in-hospital mortality in colon and rectal surgery. J Am Coll Surg. 2012;215(2):255-61.

2. Mann RE, Smart RG, Govoni R. The epidemiology of alcoholic liver disease. Alcohol Res Health. 2003;27(3):209-19.

3. Telem DA, Schiano T, Goldstone R, Han DK, Buch KE, Chin EH, et al. Factors that predict outcome of abdominal operations in patients with advanced cirrhosis. Clin Gastroenterol Hepatol. 2010;8(5):451-7, quiz e58.

4. Meunier K, Mucci S, Quentin V, Azoulay R, Arnaud JP, Hamy A. Colorectal surgery in cirrhotic patients: assessment of operative morbidity and mortality. Dis Colon Rectum. 2008;51(8):1225-31.

5. Douard R, Lentschener C, Ozier Y, Dousset B. Operative risks of digestive surgery in cirrhotic patients. Gastroenterol Clin Biol. 2009:33(6-7):555-64.

6. Paolino J, Steinhagen RM. Colorectal surgery in cirrhotic patients. Scientific World Journal. 2014;2014:239-93.

7. Ziser A, Plevak DJ, Wiesner RH, Rakela J, Offord KP, Brown DL. Morbidity and mortality in cirrhotic patients undergoing anesthesia and surgery. Anesthesiology. 1999;90(1):42-53.

8. Rice HE, O'Keefe GE, Helton WS, Johansen K. Morbid prognostic features in patients with chronic liver failure undergoing nonhepatic surgery. Arch Surg. 1997;132(8):880-4; discussion 4-5.

9. de Goede B, Klitsie PJ, Lange JF, Metselaar HJ, Kazemier G. Morbidity and mortality related to non-hepatic surgery in patients with liver cirrhosis: a systematic review. Best Pract Res Clin Gastroenterol. 2012;26(1):47-59.

10. Adani GL. Colorectal surgery in cirrhotic patients: the role of laparoscopy. Ann Surg. 2014;259(4):e57.

11. Cobb WS, Heniford BT, Burns JM, Carbonell AM, Matthews BD,
Kercher KW. Cirrhosis is not a contraindication to laparoscopic surgery. Surg Endosc. 2005;19(3):418-23.

12. Neeff H, Mariaskin D, Spangenberg HC, Hopt UT, Makowiec F. Perioperative mortality after non-hepatic general surgery in patients with liver cirrhosis: an analysis of 138 operations in the 2000s using Child and MELD scores. J Gastrointest Surg. 2011;15(1):1-11.

13. Gervaz P, Pak-art R, Nivatvongs S, Wolff BG, Larson D, Ringel S. Colorectal adenocarcinoma in cirrhotic patients. J Am Coll Surg. 2003;196(6):874-9.

14. Teh SH, Nagorney DM, Stevens SR, Offord KP, Therneau TM, Plevak DJ, et al. Risk factors for mortality after surgery in patients with cirrhosis. Gastroenterology. 2007;132(4):1261-9.

15. Hedrick TL, Swenson BR, Friel CM. Model for End-stage Liver Disease (MELD) in predicting postoperative mortality of patients undergoing colorectal surgery. Am Surg. 2013;79(4):347-52.

16. Northup PG, Wanamaker RC, Lee VD, Adams RB, Berg CL. Model for End-Stage Liver Disease (MELD) predicts nontransplant surgical mortality in patients with cirrhosis. Ann Surg. 2005; 242(2):244-51.

17. Lee JH, Yu CS, Lee JL, Kim CW, Yoon YS, Park IJ, et al. Factors affecting the postoperative morbidity and survival of patients with liver cirrhosis following colorectal cancer surgery. Int J Colorectal Dis. 2017:32(4):521-30.

18. Jakab F, Rath Z, Sugar I, Faller J. Complications following major abdominal surgery in cirrhotic patients. Acta Chir Hung. 1991;32(4):279-85

19. Kaser SA, Hofmann I, Willi N, Stickel F, Maurer CA. Liver Cirrhosis/ Severe Fibrosis Is a Risk Factor for Anastomotic Leakage after Colorectal Surgery. Gastroenterol Res Pract. 2016;2016:1563037.

20. Fucini C, Wolff BG, Dozois RR. Bleeding from peristomal varices: perspectives on prevention and treatment. Dis Colon Rectum. 1991;34(12):1073-8.

21. Sabbagh C, Chatelain D, Nguyen-Khac E, Rebibo L, Joly JP, Regimbeau JM. Management of colorectal cancer in patients with cirrhosis: A retrospective, case-matched study of short- and longterm outcomes. Dig Liver Dis. 2016;48(4):429-34.

22. Sabbagh C, Cosse C, Chauffert B, Nguyen-Khac E, Joly JP, Yzet T, et al. Management of colon cancer in patients with cirrhosis: A review. Surg Oncol. 2015;24(3):187-93.

23. Sabbagh C, Fuks D, Regimbeau JM. Non-hepatic gastrointestinal surgery in patients with cirrhosis. J Visc Surg. 2014;151(3):203-11.

24. Gross CP, Guo Z, McAvay GJ, Allore HG, Young M, Tinetti ME. Multimorbidity and survival in older persons with colorectal cancer. J Am Geriatr Soc. 2006;54(12):1898-904. 